\title{
PERANCANGAN PERHITUNGAN LABA RUGI PADA PT. XYZ
}

\author{
Akhsani Taqwiym ${ }^{1)}$ \\ 1) Komputerisasi Akuntansi STMIK GI MDP, Jl. Rajawali No. 14, Palembang \\ email : akhsani.taqwiym@mdp.ac.id ${ }^{l)}$
}

\begin{abstract}
Abstraksi
Perancangan aplikasi perhitungan laba rugi adalah aplikasi yang dirancang guna mempermudah dalam proses pencatatan laba rugi secara digital, cepat dan hasilnya lebih akurat dibandingkan dengan metode manual. Penelitian ini menggunakan metode waterfall yang dimulai dengan analisis kebutuhan, desain, pembuatan kode program, pengujian, pendukung atau pemeliharaan. Perancangan aplikasi perhitungan laba rugi dirancang dan dikonsep berdasarkan permasalahan yang terjadi di PT. XYZ dimana pencatatan transaksi yang tidak terdokumentasi dengan baik sehingga menyebabkan selisih pada pencatatan laba rugi. Laporan laba rugi PT. XYZ meliputi dana proyek, bahan baku yang dibutuhkan, bahan baku yang dibeli, bahan baku yang terpakai, dan laporan laba rugi. Program aplikasi menggunakan Microsoft Visual Studio 2013 dan MYSQL 2012. Didalam akses aplikasi digunakan satu admin yang mencatat dan mengkoordinir semua kegiatan dan memantau semua kegiatan transaksi masuk dan keluar. Diharapkan dengan adanya aplikasi ini dapat membantu dalam proses pencatatan laporan kegiatan dalam penyelesaian suatu proyek sehingga tidak terjadi selisih pada laporan akhir.
\end{abstract}

Kata Kunci :

Perhitungan Laba Rugi, Microsoft Visual Basic Net 2013, dan MySQL.

\begin{abstract}
The design of the profit and loss calculation application is an application designed to facilitate the process of recording profit and loss digitally, quickly and the results are more accurate than the manual method. The method used in this study is the waterfall method that starts with needs analysis, design, program code creation, testing, support or maintenance. The design of the profit and loss calculation application is designed and conceptualized based on the problems that occur at PT. XYZ where the recording of transactions that are not well documented causes a difference in the recording of profit and loss. PT. XYZ includes project funds, raw materials needed, raw materials purchased, raw materials used, and income statement. The application program uses Microsoft Visual Studio 2013 and MYSQL 2012. In the application access, an admin is used to record and coordinate all activities and monitor all incoming and outgoing transaction activities. It is expected that this application can assist in the process of recording activity reports in the completion of a project so that there is no difference in the final report.
\end{abstract}

\section{Keywords :}

Calculation of Income, Microsoft Visual Basic Net 2013, and MySQL.

\section{PENDAHULUAN}

Laporan laba rugi adalah suatu laporan keuangan yang di dalamnya menjelaskan tentang kinerja keuangan suatu entitas bisnis dalam suatu periode tertentu. Penyusunan laporan laba rugi bertujuan untuk memberikan informasi yang dibutuhkan sebagai dasar pengambilan sebuah keputusan [1]. Pada umumnya pencatatan laporan laba rugi pada sebuah perusahaan di proses secara manual maupun digital. Pencatatan laba rugi pada sebuah perusahaan jika dicatat secara manual bukanlah sebuah masalah dikarenakan pencatatan secara manual data tetap tercatat dan terdokumentasi dengan baik. Namun ada kalanya pencatatan secara manual, 
terjadi kesalahan input bahkan tidak tercatat. Hal ini akan mempengaruhi hasil perhitungan. Pencatatan secara manual menimbulkan banyak kekurangan dari efisien waktu, kesalahan pencatatan akibat dari bagian pencatatan dan lain sebagainya. Teknologi berkembang dengan tujuan mempermudah pekerjaaan manusia terutama dalam proses pencatatan laba rugi pada sebuah perusahaan [2].

Dalam pencatatan yang dilakukan secara manual terdapat banyak kemungkinan yang terjadi adapun yang sering terjadi adalah kesalahan pada pencatatan yang tercatat, tanggal transaksi yang keliru, kegiatan transaksi yang tercatat maupun yang tidak tercatat. Hal-hal yang sering terjadi menimbulkan kerugian untuk sebuah perusahaan dikarenakan memakan waktu lebih untuk membenarkan transaksi agar menjadi sesuai dengan kenyataan, memakan waktu lebih dalam proses pencarian hal ini akan sangat menggangu di saat audit ataupun proses pengambilan keputusan. Sehingga dirasa tidak efisien [3].

Untuk mengatasi permasalahan pada PT XYZ maka dirancanglah sebuah rancangan aplikasi berbasis dekstop. Tujuan perancangan aplikasi ini adalah untuk menyelesaikan permasalahan yang terjadi di PT XYZ, antara lain menghemat waktu dalam proses pencarian data, mempercepat proses pencatatan, mengurangi resiko kesalahan input oleh bagian administrasi. Sehingga dengan adanya perancangan aplikasi ini diharapkan proses pencatatan dan lapoan laba rugi menjadi lebih cepat, tepat, dan efisien. Untuk merancang aplikasi digunakan metode waterfall dari analisis kebutuhan, desain, pembuatan kode program, pengujian, pendukung atau pemeliharan. Analisis kebutuhan sistem yang akan dibuat dalam bentuk yang dapat dimengerti, tahap selanjutnya yaitu desain tahap ini merupakan pengembangan sistem yang akan dihasilkan dalam bentuk keseluruhan, selanjutnya setelah melakukan tahap desain melakukan tahap implementasi secara seluruh desain tersebut diubah dalam bentuk kode-kode program yang selanjutnya akan menjadi satu sistem tahap selanjutnya implementasi pengguna dengan melakukan uji coba terhadap sistem tersebut, dan tahap terakhir melakukan pemeliharan sistem yang telah dibuat untuk dikembangkan lagi, atau dilakukan (perubahaan) untuk perbaikan sistem kedepannya.

\subsection{TUJUAN PENELITIAN}

Adapun tujuan penelitian ini adalah sebagai berikut:

1. Membantu mencatat laporan kegiatan dalam proses penyelesaian suatu proyek PT XYZ agar tidak terjadi selisih pada laporan akhir. 
URL : https://jurnal.machung.ac.id/index.php/kurawal

2. Membuat aplikasi yang menampilkan seluruh histori laporan transaksi dan membuat aplikasi yang menampilkan laporan laba rugi berdasarkan hasil laporan transaksi.

\subsection{BATASAN PENELITIAN}

Adapun batasan penelitian ini adalah sebagai berikut:

1. Laporan laba rugi PT XYZ meliputi dana proyek, bahan baku yang dibutuhkan, bahan baku yang dibeli, bahan baku yang terpakai, dan laporan meliputi laporan pembelian, laporan bahan baku terpakai, dan laporan laba rugi.

2. Program aplikasi menggunakan Microsoft Visual Studio 2013 dan MySq1 2012. Didalam akses aplikasi, digunanakan oleh satu admin yang mencatat dan mengkoordinir semua kegiatan manual da mengubahnya menjadi digital.

\section{METODOLOGI PENELITIAN}

Penelitian ini direncanakan akan merancang suatu sistem untuk mempermudah dan mengefisiensikan waktu dalam proses pencatatan laporan laba rugi sehingga menghasilkan laporan yang akurat serta memberikan ruang yang aman dalam penyimpanan data transaksi sehingga memudahkan dalam proses pencarian data yang dibutuhkan.Penelitian ini akan mengadopsi rekayasa perangkat lunak model waterfall[5]. Model ini merupakan model yang paling banyak dipakai oleh para pengembang software. Ada lima tahap dalam model waterfall, yaitu requirement Analysis, system Design, implementation, Integration dan Testing, Operations dan Maintenance. Sesuai dengan namanya waterfall (air terjun) maka tahapan ini disusun bertingkat, setiap tahap dalam model ini dilakukan berurutan, satu sebelum yang lainnya.

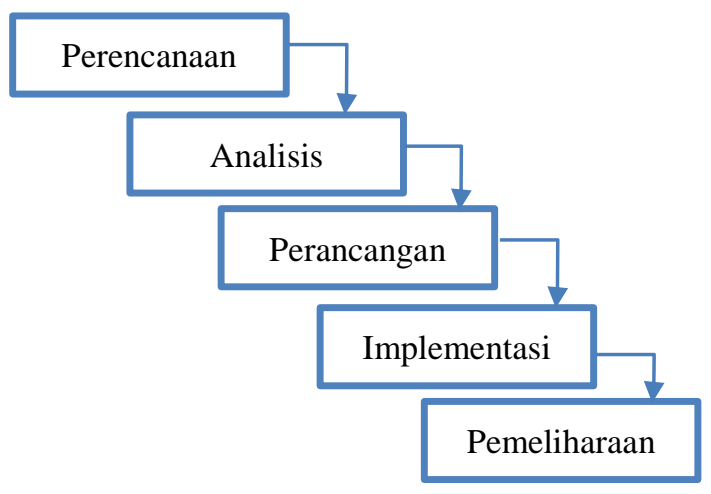

Gambar 1 Tahapan Model Waterfall. 
Langkah-langkah penelitian sebagai berikut:

1. Menganalisa proses administrasi dan dokumentasi pencatatan laporan laba rugi yang dijalankan selama ini.

2. Melakukan perancangan sistem. Analisis sistem dimodelkan ke dalam satu bentuk rancangan sistem.

3. Menganalisa permasalahan yang timbul. Dalam hal ini proses pencatatan sesuai ketentuan dan peraturan yang diterapkan.

4. Membuat kesimpulan penelitian untuk mencapai solusi dan diharapkan diperoleh kesimpulan yang akan memenuhi tujuan penelitian.

Teknik pengumpulan data yang digunakan didalam penelitian ini ialah (1) wawancara, (2) observasi dan (3) studi pustaka[6]. Wawancara memungkinkan analisis sistem sebagai pewawancara (interviewer) untuk mengumpulkan data sacara tatap muka langsung dengan orang yang diwawancarai (interview). Didalam penelitian ini penulis melakukan wawacara dengan dosen untuk memperoleh data yang lebih akurat. Observasi adalah salah satu teknik pencarian data paling efektif untuk pemahaman suatu system [7]. Teknik observasi dilakukan bersama-sama dengan pengumpulan kebutuhan sistem yang lain. Penulis mengamati dan menganalisa proses pembuatan soal, alur sistem yang berjalan. Studi pustaka merupakan metode yang dilakukan dengan cara mengumpulkan, membaca, dan mempelajari data-data yang ada dari berbagai media, seperti buku-buku, hasil karya tulis, jurnal-jurnal penelitian atau artikel-artikel dari internet yang berhubungan dengan masalah yang dibahas [8].

\section{HASIL DAN PEMBAHASAN}

\subsection{Rancangan Basis Data}

Entity Relationship Diagram adalah diagram yang menjelaskan hubungan antara beberapa data yang disajikan dalam bentuk table[9]. ERD yang akan dikembangkan pada PT. XYZ dalam bidang perhitungan laba rugi yang terjadi didalam perusahaan. Diagram tersebut ditunjukkan pada Gambar 2

\subsection{Transformasi Diagram Entity Relationship ke Tabel Relasi}

Dalam perancangan sistem ini penulis menggunakan beberapa tabel yaitu tabel pengguna, tabel proyek, tabel list barang, tabel pembelian bahan baku, dan tabel bahan baku terpakai. 
URL : https://jurnal.machung.ac.id/index.php/kurawal

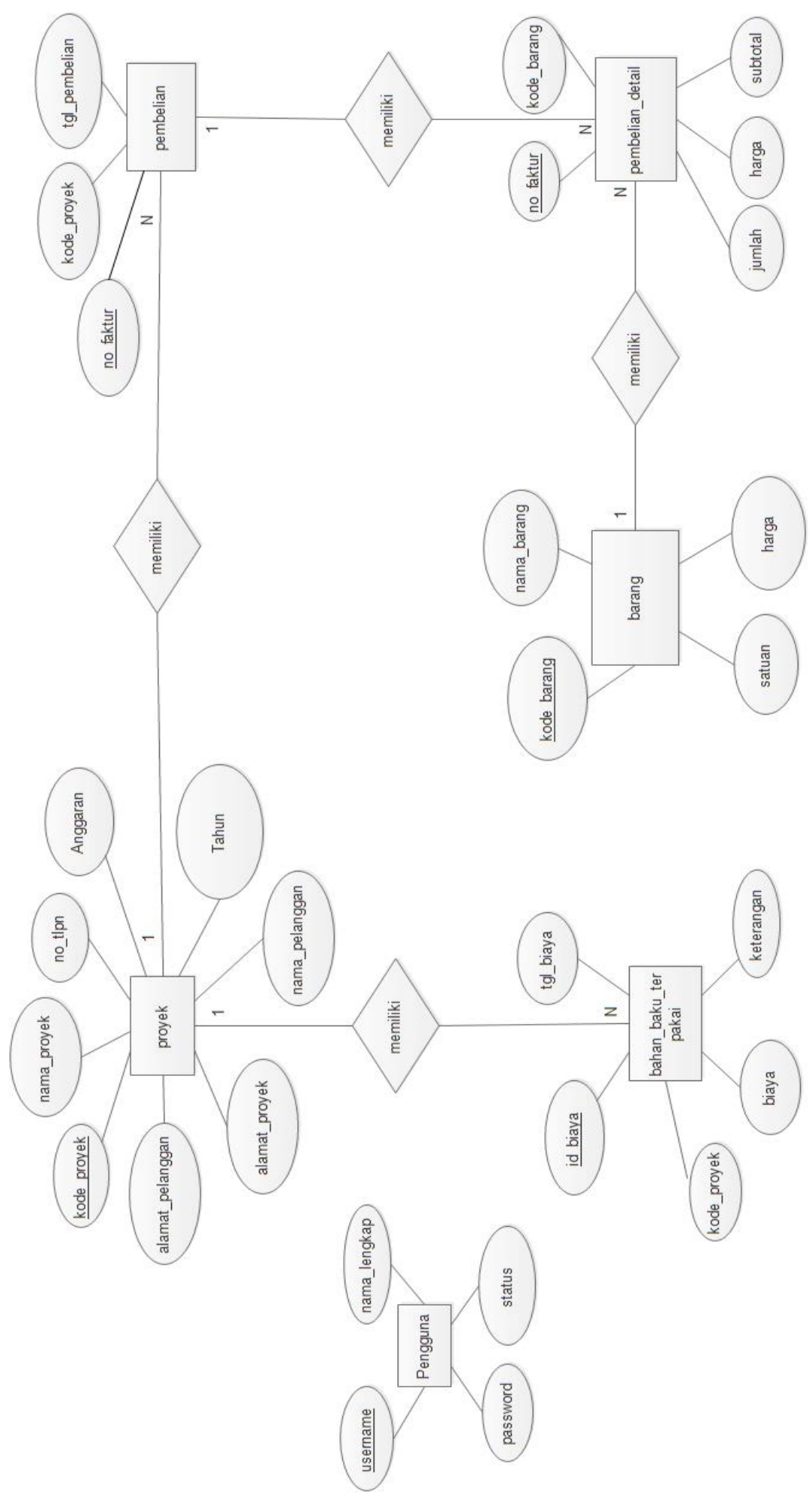

Gambar 2 Entity Relationship Diagram.

1. Dari transformasi pertama dalam diagram Entity Relationship ini maka berikut tabel pengguna yang dapat dilihat pada Tabel 1 . 
URL : https://jurnal.machung.ac.id/index.php/kurawal

Tabel 1 Pengguna

\begin{tabular}{|l|l|l|l|}
\hline Username & nama_lengkap & password & Status \\
\hline & & & \\
\hline
\end{tabular}

2. Transformasi kedua dalam diagram Entity Relationship (ERD) yang terdiri dari tabel proyek dan tabel pembelian. Transformasi kedua ini dapat dilihat pada Tabel 2.

Tabel 2 Proyek

\begin{tabular}{|l|l|l|l|l|l|l|l|}
\hline $\begin{array}{l}\text { kode__ } \\
\text { proyek }\end{array}$ & $\begin{array}{l}\text { nama_p } \\
\text { royek }\end{array}$ & $\begin{array}{l}\text { nama_pela } \\
\text { nggan }\end{array}$ & $\begin{array}{l}\text { alamat_pr } \\
\text { oyek }\end{array}$ & $\begin{array}{l}\text { alamat_pe } \\
\text { langgan }\end{array}$ & $\begin{array}{l}\text { no_tl } \\
\text { pn }\end{array}$ & $\begin{array}{l}\text { Anggar } \\
\text { an }\end{array}$ & Tahun \\
\hline & & & & & & & \\
\hline
\end{tabular}

Berikut ini tabel pembelian yang dapat dilihat pada Tabel 3

Tabel 3 Pembelian

\begin{tabular}{|l|c|c|}
\hline no_faktur & tgl_Pembelian & kode_Proyek \\
\hline & & \\
\hline
\end{tabular}

3. Dari transformasi ketiga dalam diagram Entity Relationship (ERD) ini maka berikut tabel pembelian_detail yang dapat dilihat pada Tabel 4.

Tabel 4 Pembelian_Detail

\begin{tabular}{|l|l|l|l|l|}
\hline no_faktur & kode_barang & harga & jumlah & Subtotal \\
\hline & & & & \\
\hline
\end{tabular}

4. Dari transformasi keempat dalam diagram Entity Relationship (ERD) ini maka berikut tabel barang yang dapat dilihat pada Tabel 5.

Tabel 5 Barang

\begin{tabular}{|l|l|l|l|}
\hline kode_barang & nama_barang & satuan & Harga \\
\hline & & & \\
\hline
\end{tabular}

5. Dari transformasi keempat dalam diagram Entity Relationship (ERD) ini maka berikut tabel barang_keluar yang dapat dilihat pada Tabel 6 .

Tabel 6 Bahan_Baku_Terpakai

\begin{tabular}{|l|l|l|l|l|}
\hline id_biaya & kode_proyek & tgl_biaya & Keterangan & Biaya \\
\hline & & & & \\
\hline
\end{tabular}

\subsection{Diagram Konteks}

Diagram konteks adalah diagram yang terdiri dari suatu proses dan menggambarkan ruang lingkup suatu sistem [10]. Diagram konteks merupakan level tertinggi dari DFD yang menggambarkan keseluruhan sistem. Berikut ini adalah Diagram konteks yang diusulkan untuk PT XYZ dapat dilihat pada Gambar 3 Diagram konteks 


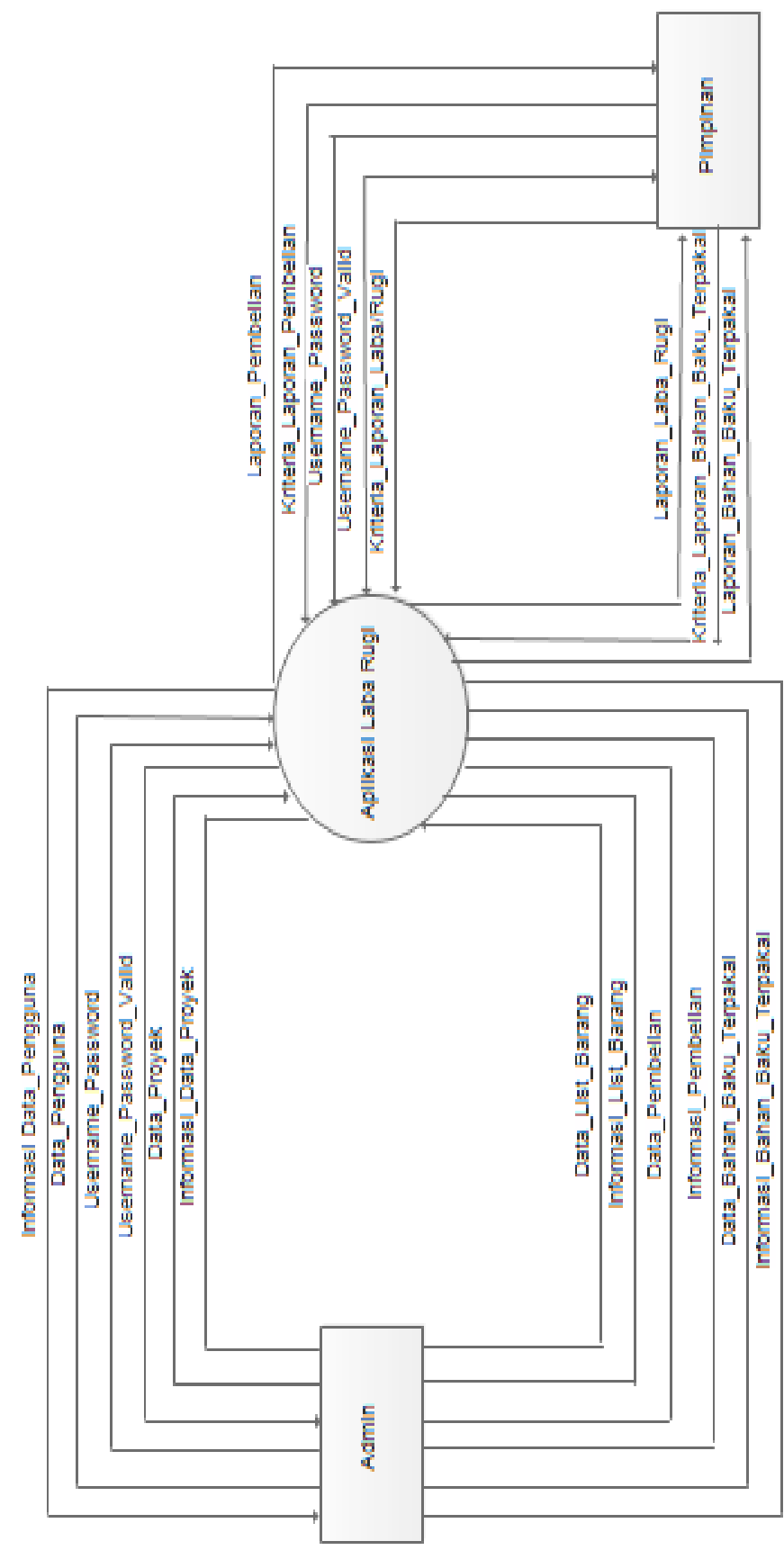

\subsection{Diagram Nol}

Gambar 3 Diagram Konteks

Diagram nol merupakan satu lingkaran besar yang mewakili lingkaran-lingkaran kecil yang ada di dalamnya. Merupakan pemecahan dari diagram Konteks. 
URL : https://jurnal.machung.ac.id/index.php/kurawal

\subsection{Diagram Rinci}

Diagram rinci merupakan diagram yang menguraikan proses apa yang ada dalam diagram Nol [11]. Diagram rinci proses Login yang diusulkan untuk PT.XYZ dapat dilihat pada gambar 4 Diagram Rinci. Sedangkan diagram rinci proyek yang diusulkan untuk PT. XYZ dapat dilihat pada gambar 5 DFD Rinci Proyek. Diagram rinci pembelian yang diusulkan untuk XYZ dapat dilihat pada gambar 6 Rinci Pembelian. Diagram rinci Persediaan yang diusulkan untuk PT. XYZ dapat dilihat pada gambar 7. Rinci Pembelian Detail

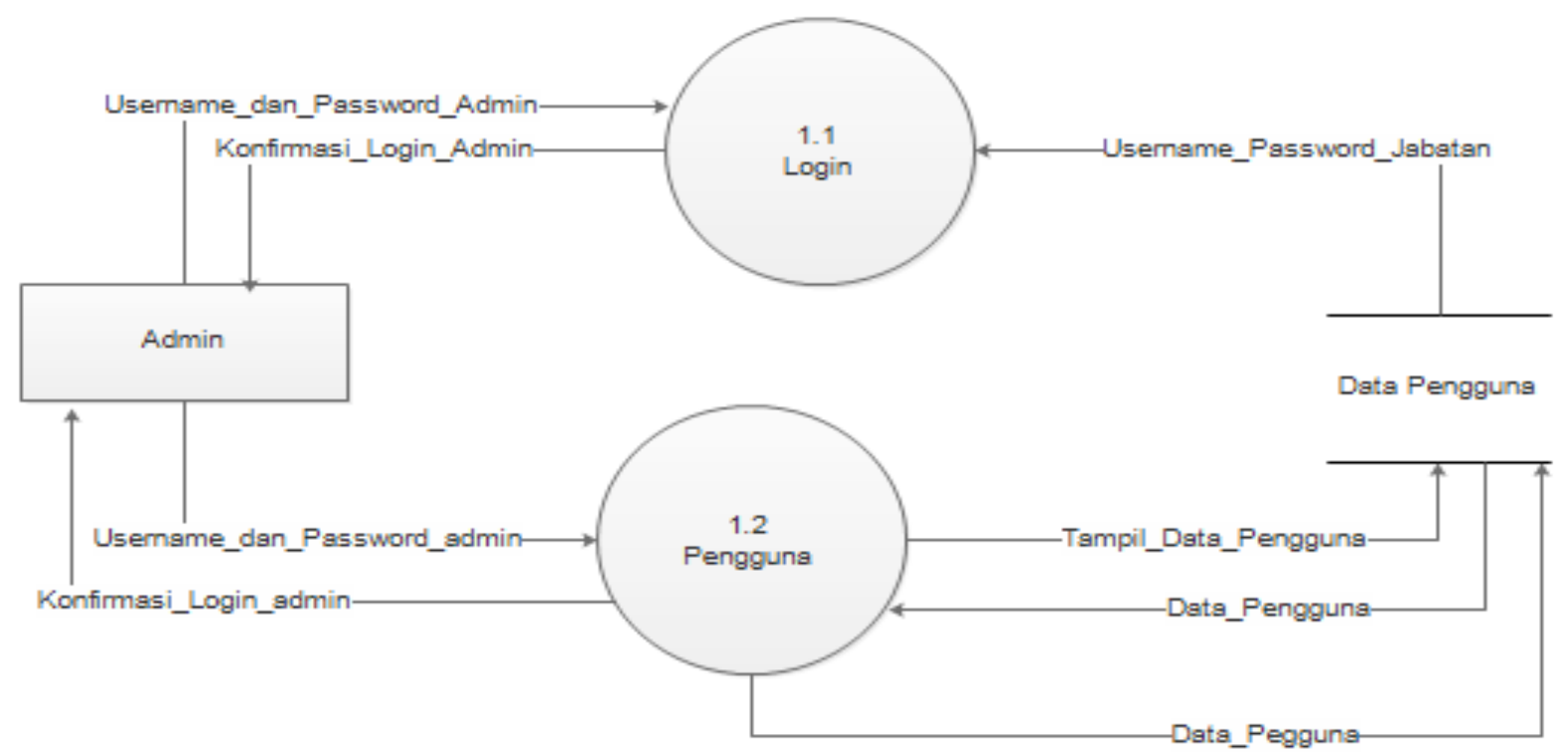

Gambar 4 DFD Rinci Login

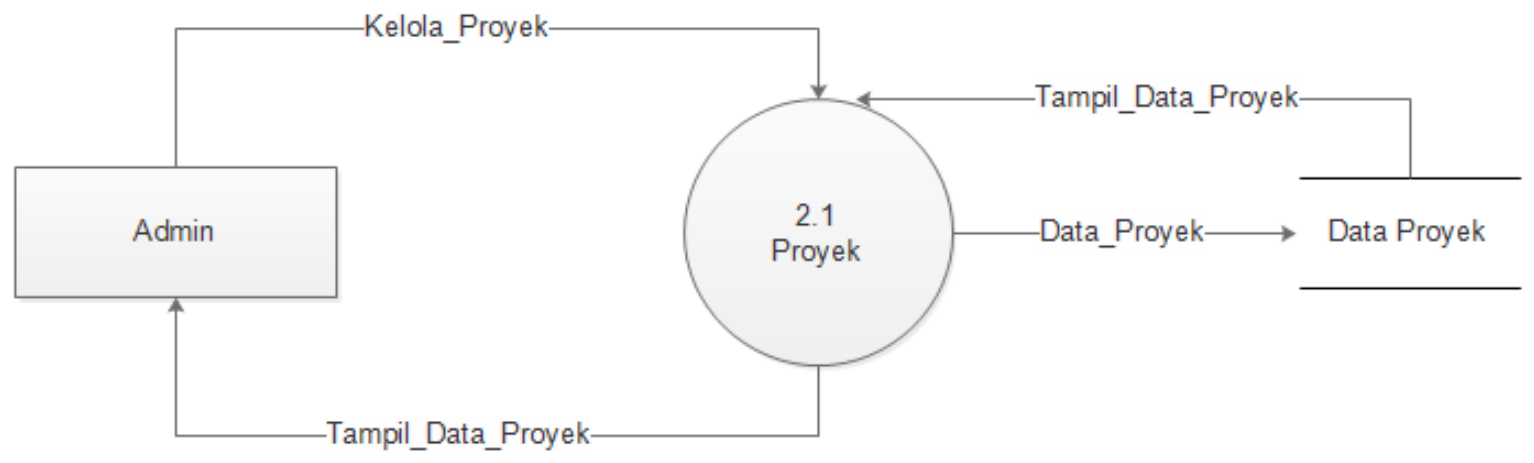

Gambar 5 DFD Rinci Proyek 


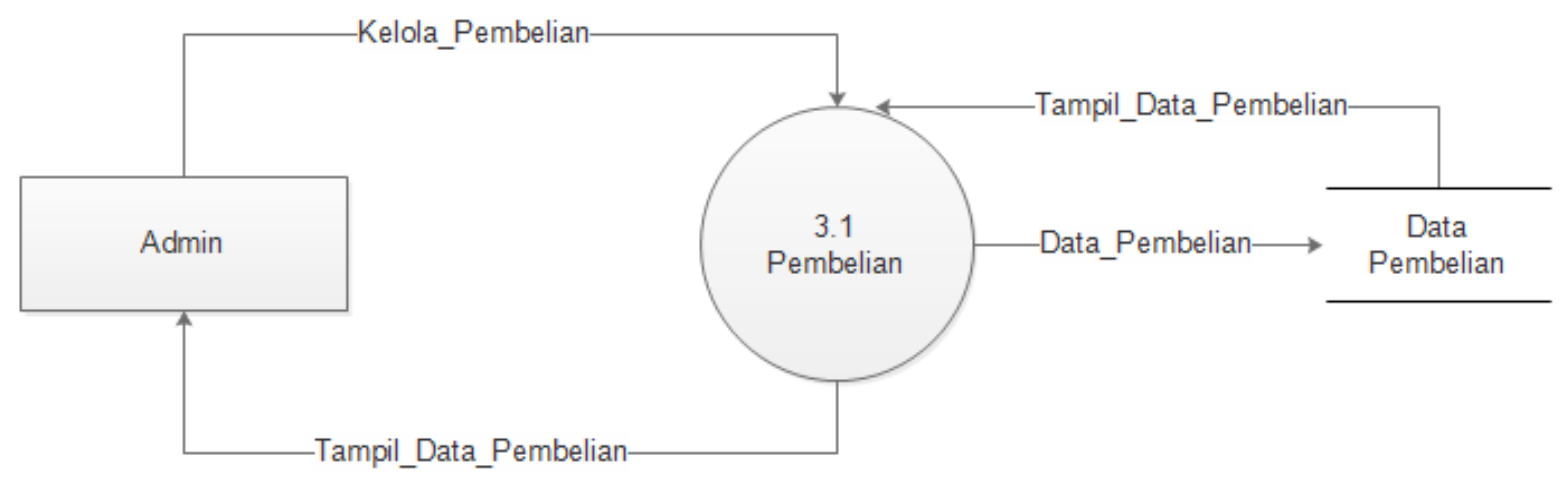

Gambar 6 Rinci Pembelian

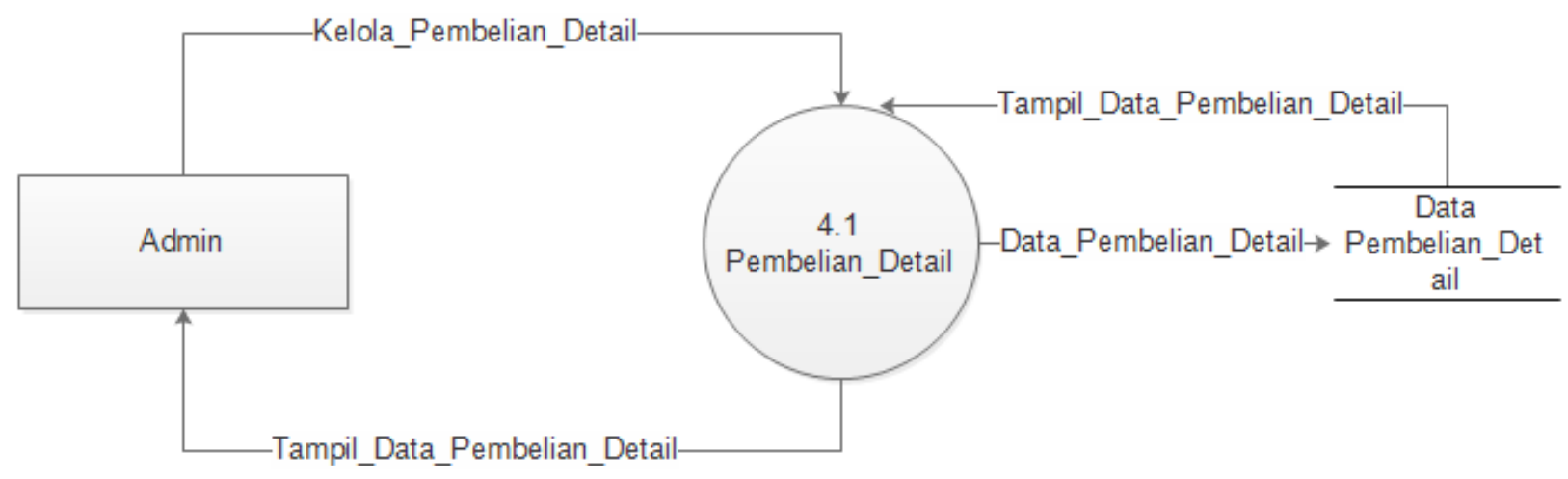

Gambar 7 Rinci Pembelian Detail

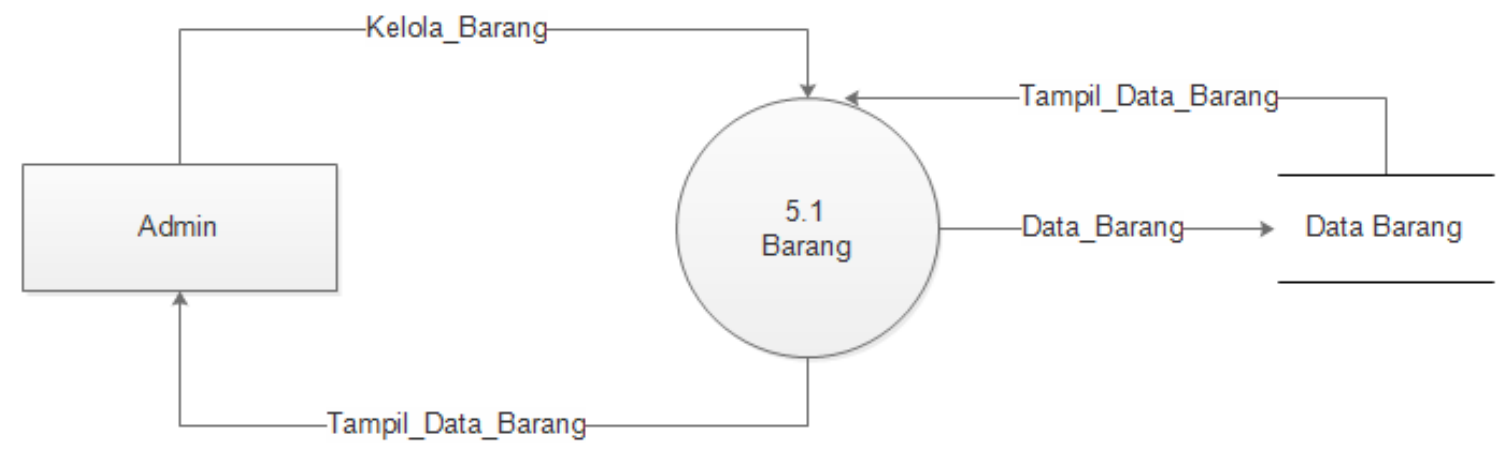

Gambar 8 Rinci Barang

Diagram rinci barang yang diusulkan untuk PT. XYZ dapat dilihat pada gambar 8. Rinci Barang. Sedangkan diagram rinci bahan baku terpakai yang diusulkan untuk PT.XYZ dapat dilihat pada gambar 9 Rinci Bahan Baku Terpakai. Dagram rinci laporan yang diusulkan untuk PT. XYZ dapat dilihat pada gambar 10 Rincian Laporan. 


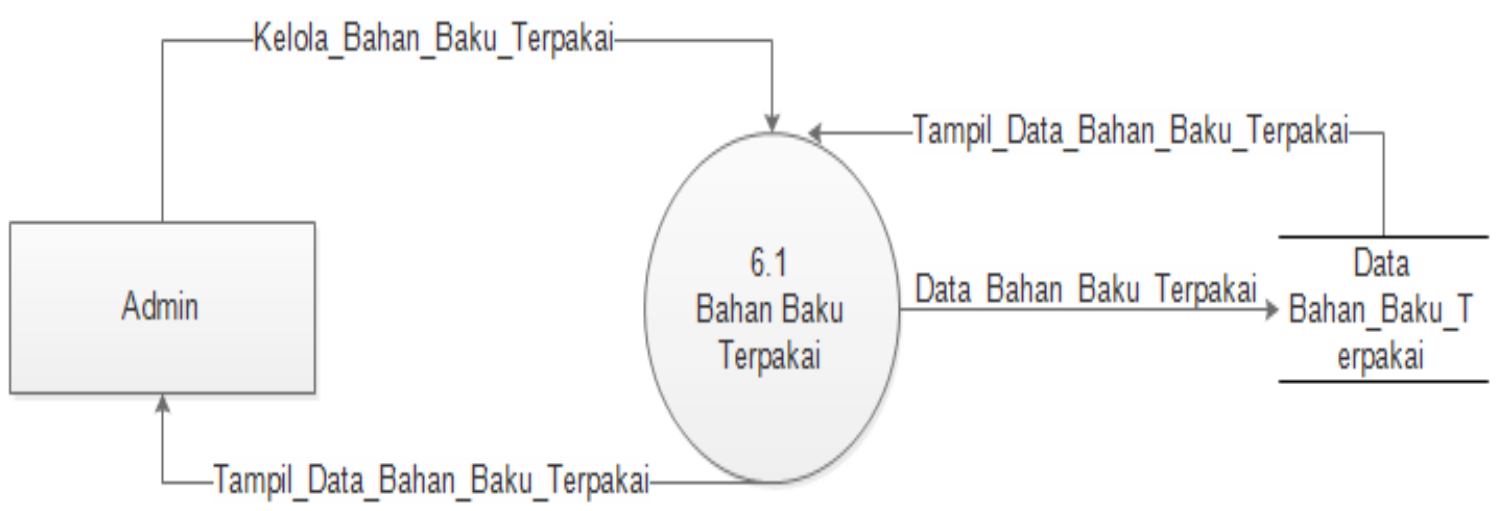

Gambar 9 Rinci Bahan Baku Terpakai

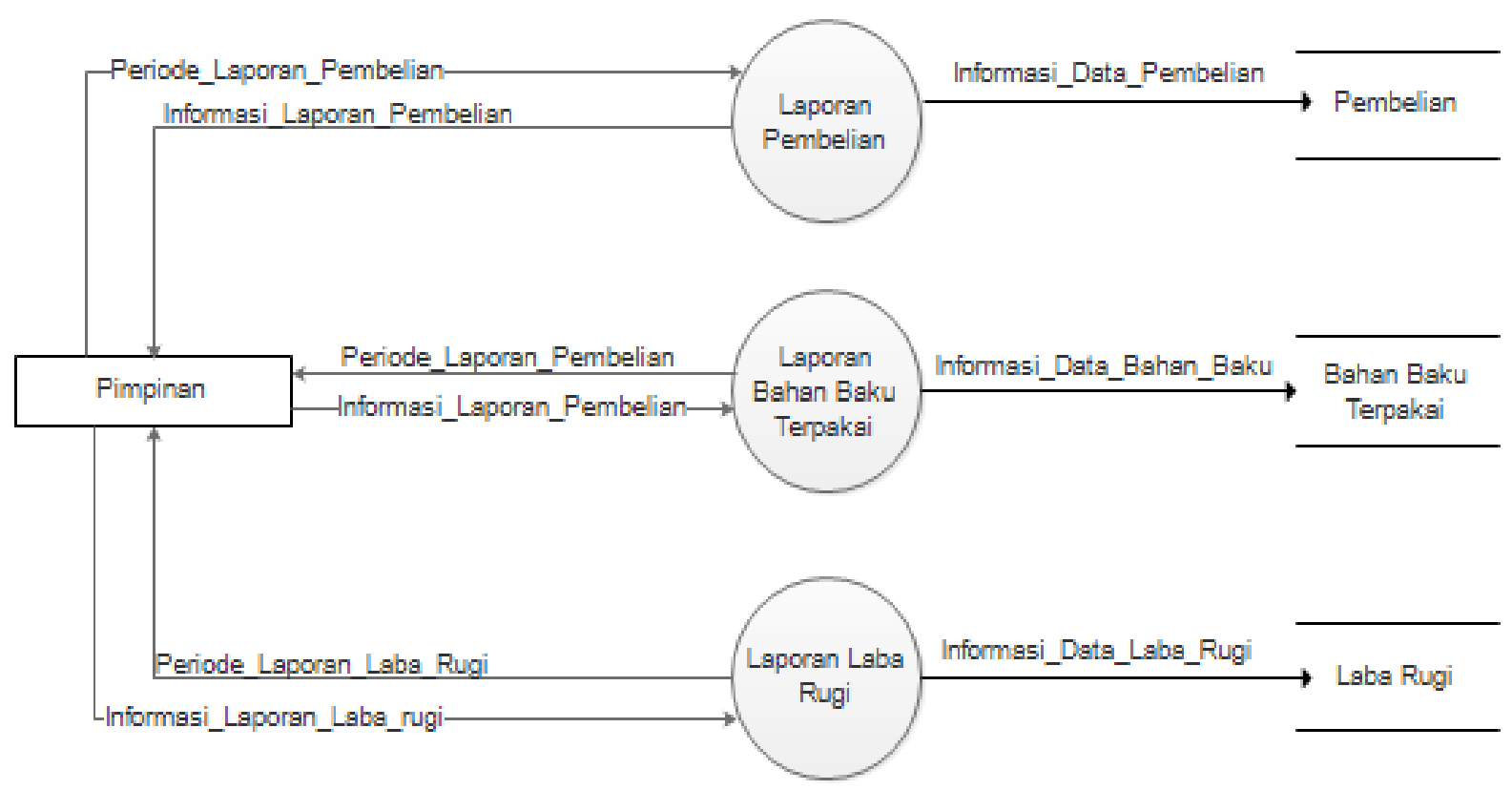

\subsection{Rancangan Layar}

Gambar 10 Rinci Laporan

\section{Login}

Rancangan form Login yang merupakan tampilan menu awal pada saat memasuki menu utama pada aplikasi.dengan memasuki Username, Password. Berikut tampilan pada saat login yang dapat dilihat pada gambar 11 Tampilan Form Login. 
URL : https://jurnal.machung.ac.id/index.php/kurawal

\section{Form Menu Utama}

Rancangan form Menu Utama. Rancangan form menu utama merupakan form yang menunjukkan semua menu yang dirancang pada aplikasi ini, antara lain : Master Menu, Pengguna, Proyek, Barang, Pembelian, Biaya Operasional, Laporan dapat dilihat pada gambar 12.

\section{Form Tambah Pengguna}

Rancangan form tambah pengguna baru untuk masuk aplikasi. Tampilan Form Tambah Pengguna yang dapat dilihat pada gambar 13 Form tambah pengguna.

\section{Form Proyek}

Rancangan Form Data Proyek menunjukkan tampilan daftar proyek yang terdiri dari Kode Proyek, Nama Proyek, Alamat Proyek, Anggaran, Tahun, Nama Pelanggan, Alamat Pelanggan, No Telepon. Dapat dilihat pada gambar 14 Form proyek.

\section{Form barang}

Rancangan Form Barang menunjukkan proses mengubah data barang terdiri dari kode barang, nama barang, satuan, harga. Dan kode barang untuk mencari data barang Dapat dilihat pada gambar 15 Form barang.

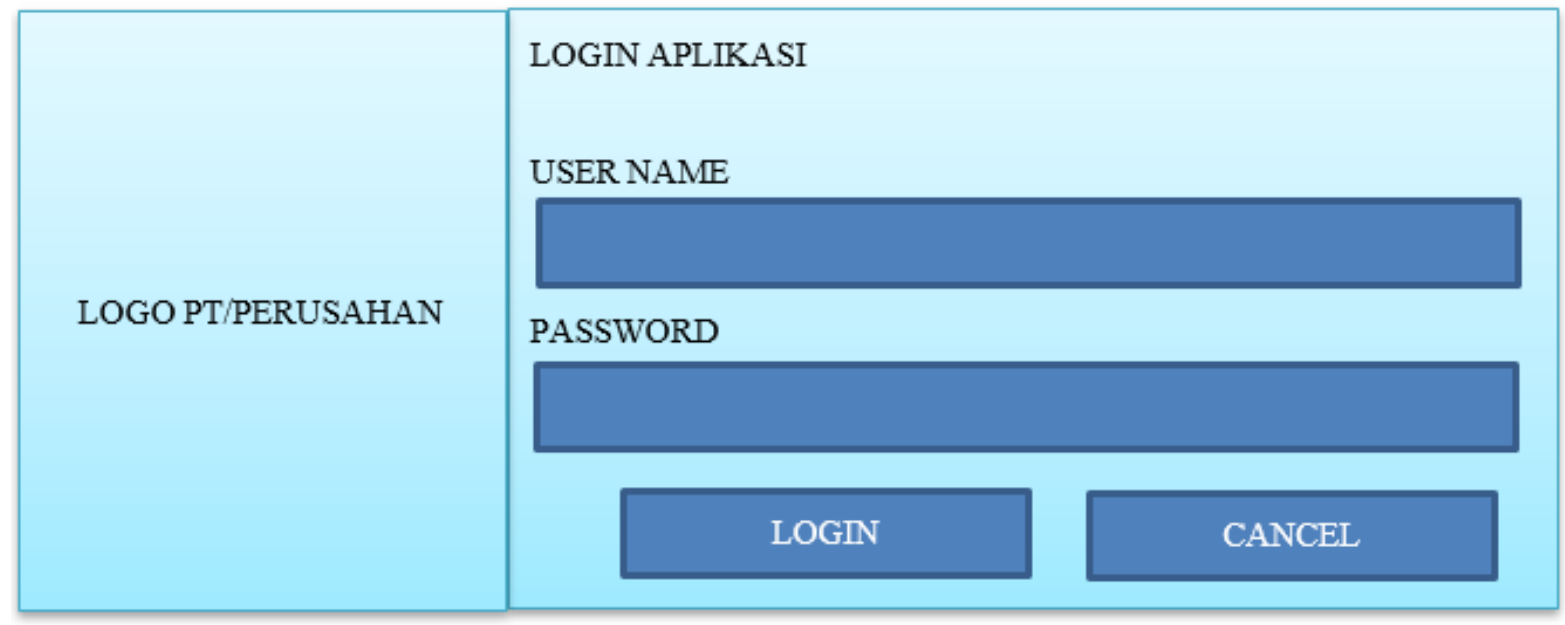

Gambar 11 Tampilan Form Login 


\section{FORM MENU UTAMA}

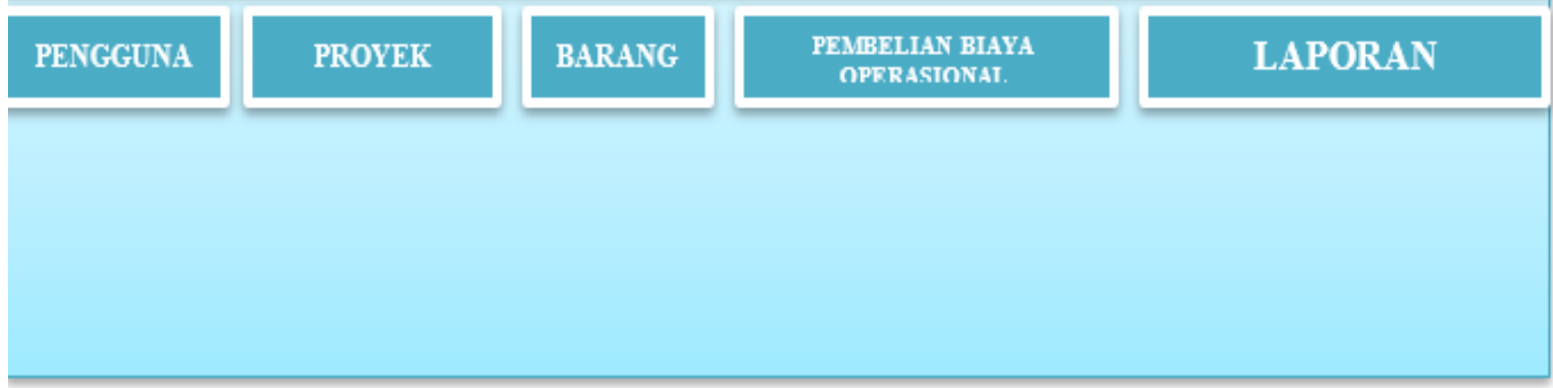

Gambar 12 Tampilan Form Menu Utama

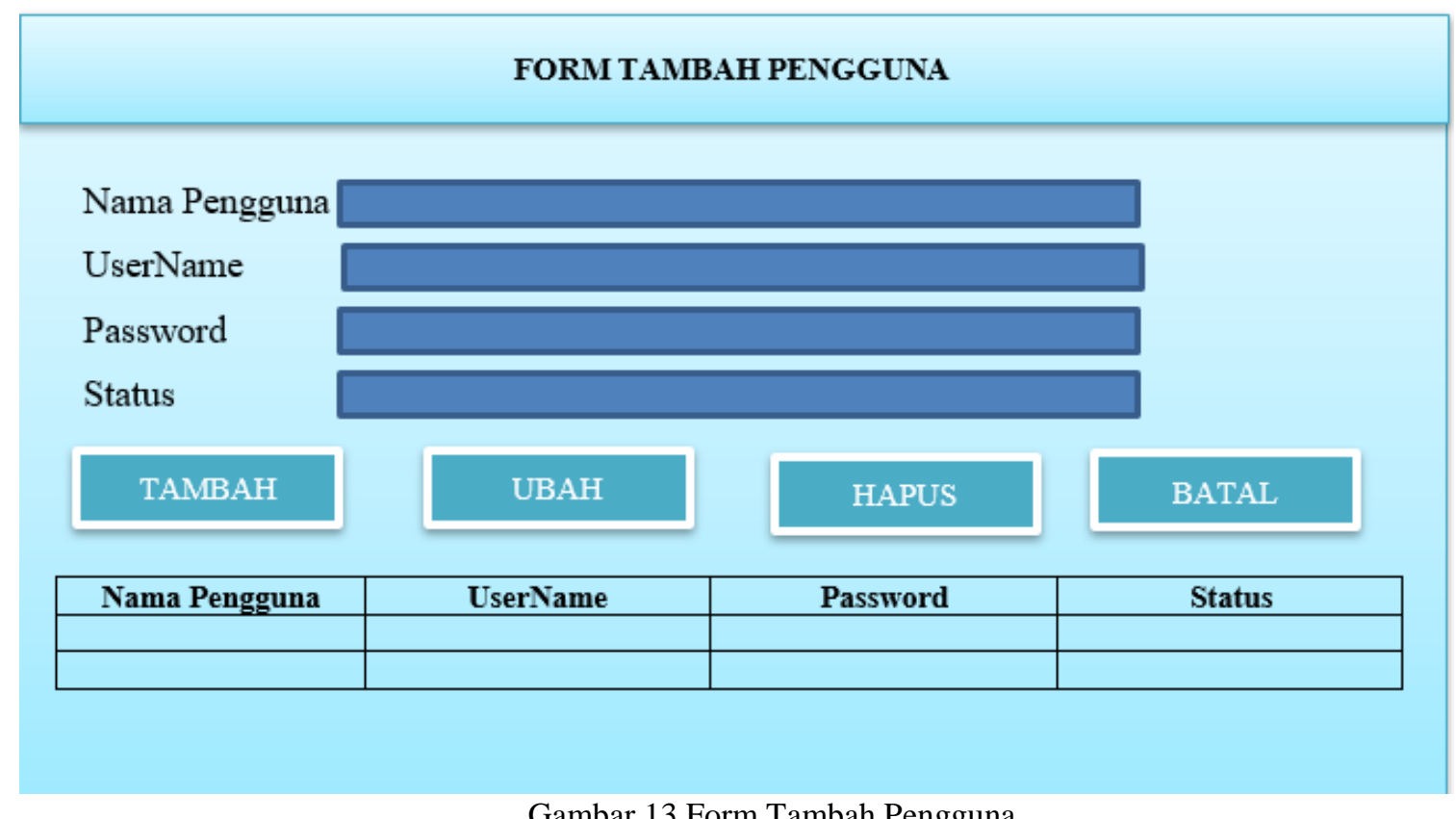

Gambar 13 Form Tambah Pengguna 
URL : https://jurnal.machung.ac.id/index.php/kurawal

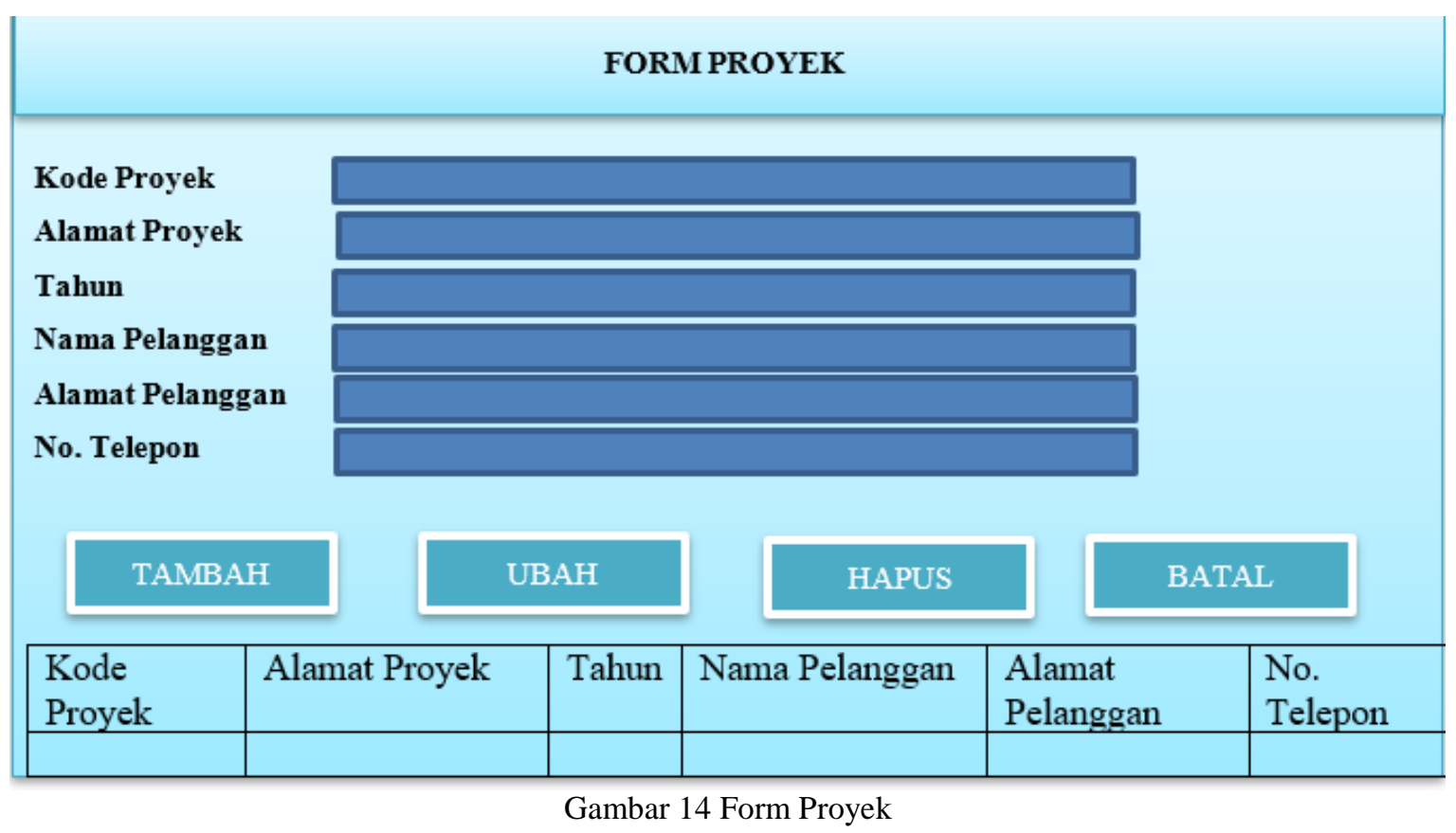

\section{Form Pembelian}

Rancangan Form Pembelian menunjukkan proses mendata pembelian barang ke pihak proyek yang terdiri dari kode barang, nama barang, harga, jumlah, subtotal, kode transaksi, tanggal transaksi, kode proyek, nama proyek Dapat dilihat pada gambar 16 Form Pembelian.

\section{Form Bahan Baku Terpakai}

Rancangan Form Bahan Baku Terpakai menunjukkan tampilan daftar tanggal transaksi, proyek stok bahan baku, pemakaian bahan baku, dan persediaan bahan baku. Dapat dilihat pada gambar 17 Form Bahan Baku Terpakai. 


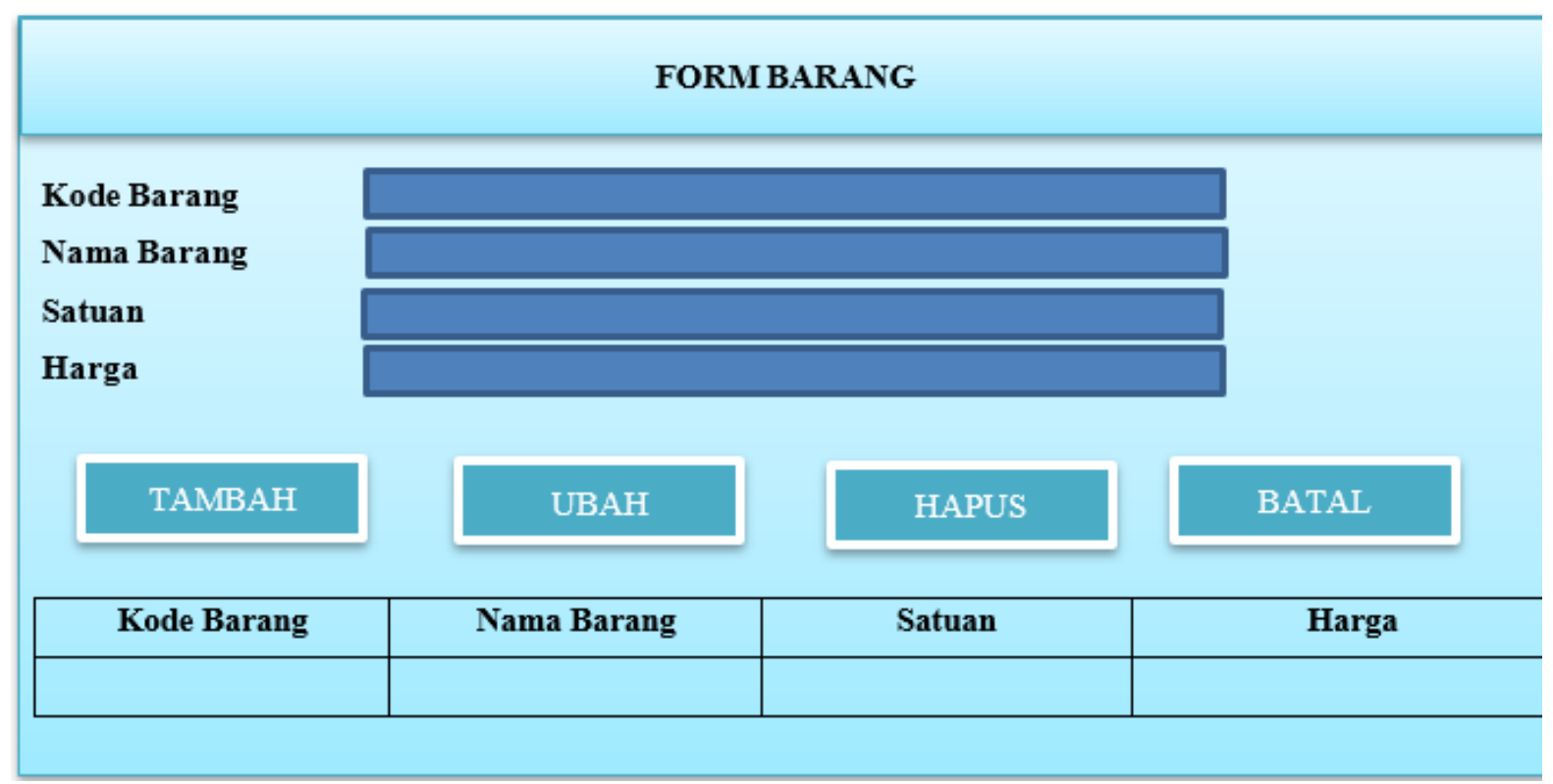

Gambar 15 Form Barang

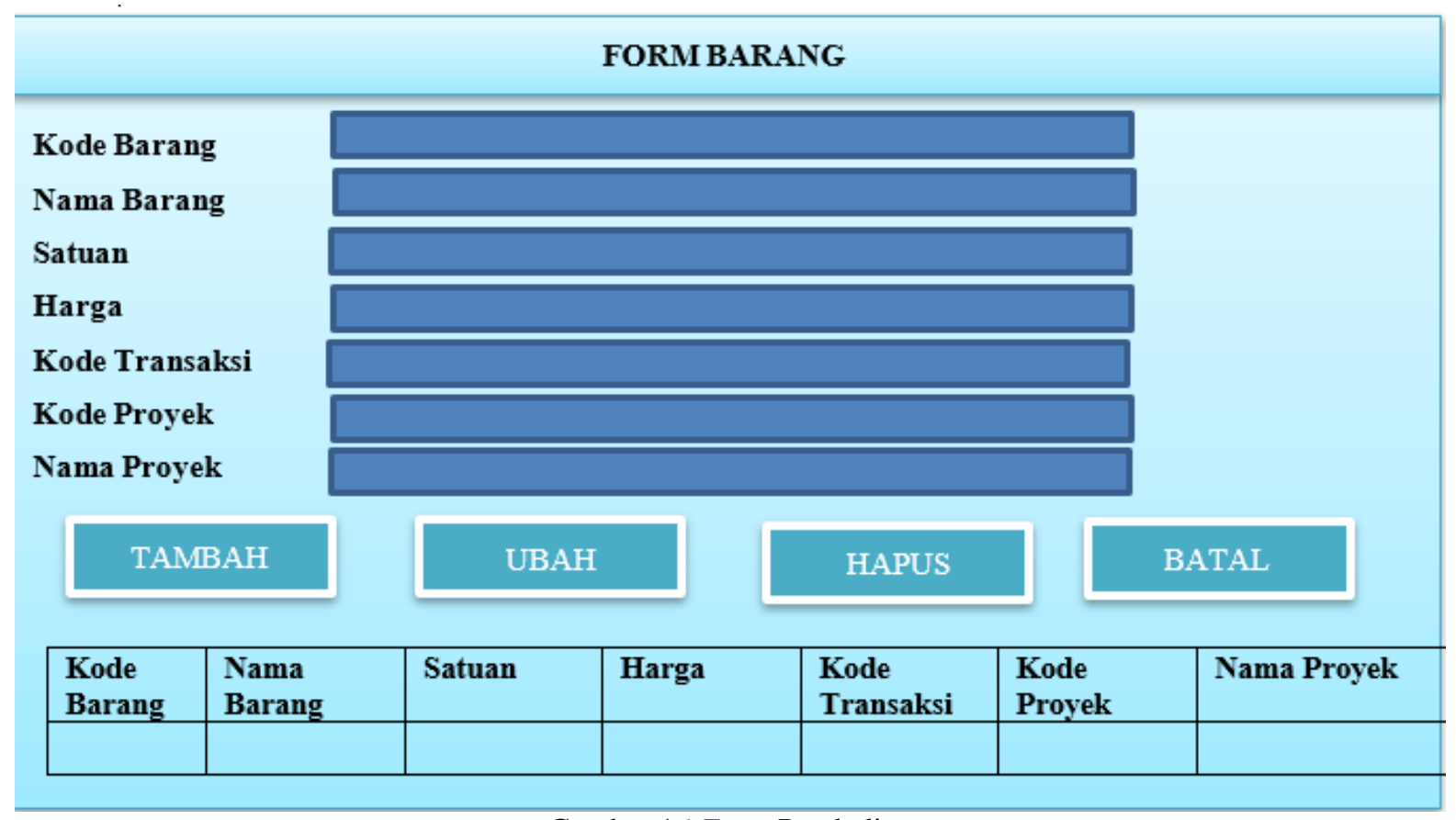

Gambar 16 Form Pembelian 
URL : https://jurnal.machung.ac.id/index.php/kurawal

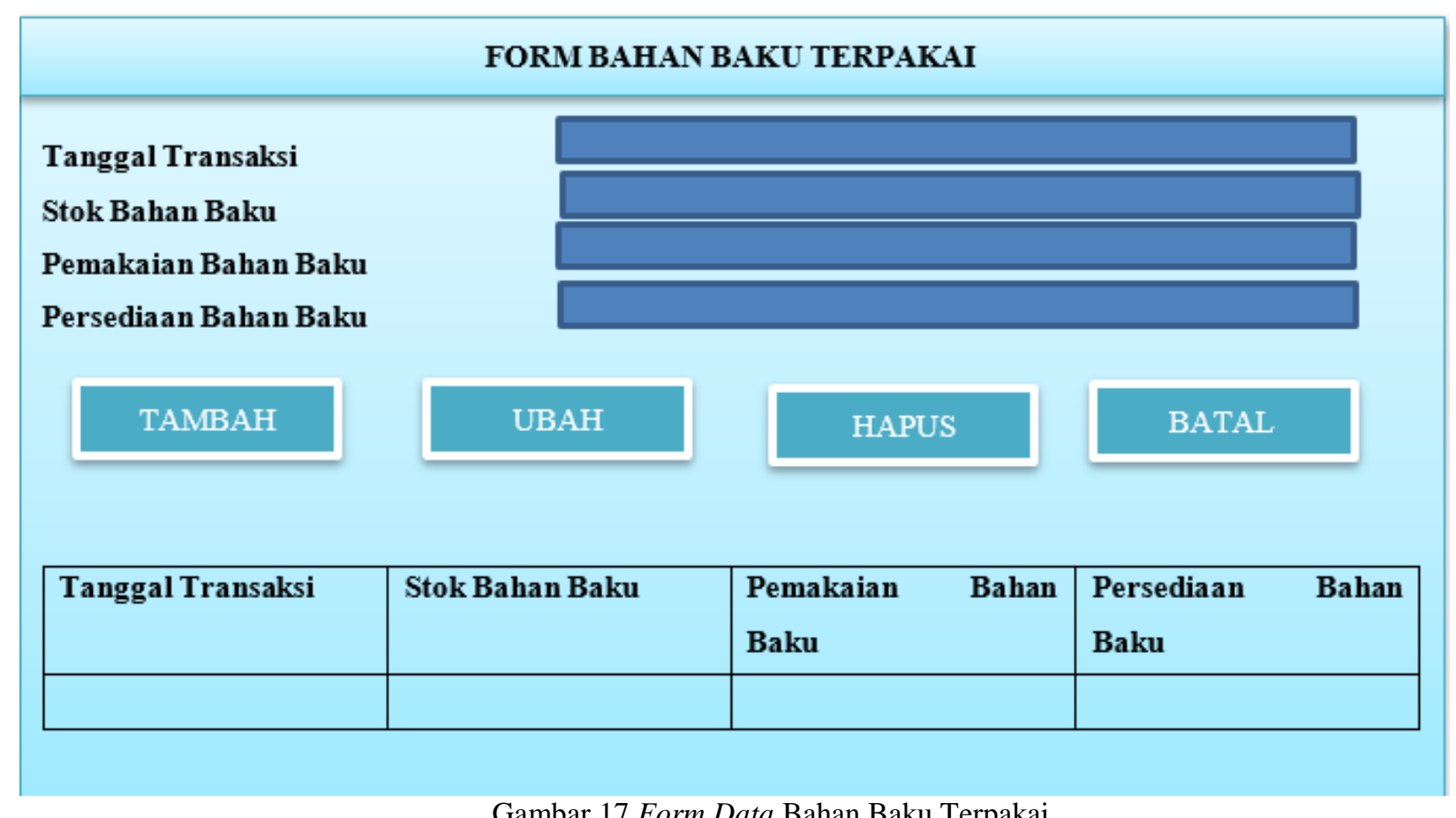

Gambar 17 Form Data Bahan Baku Terpakai

\section{Form Laporan Pembelian}

Rancangan Form Laporan Pembelian yang menunjukkan tampilan Keseluruhan Laporan Transaksi pembelian. Dapat dilihat pada gambar 18. Form Laporan Pembelian.

\section{Form Laporan Bahan Baku Terpakai}

Rancangan Form laporan bahan baku terpakai menunjukkan tampilan Keseluruhan Transaksi. Dapat dilihat pada gambar 19 Form Laporan Bahan Baku Terpakai.

\section{Form Laporan Laba Rugi}

Rancangan Form laporan laba rugi proyek menunjukkan tampilan Keseluruhan Laba Rugi Proyek. Dapat dilihat pada gambar 20 Form Laporan Laba Rugi. 
URL : https://jurnal.machung.ac.id/index.php/kurawal

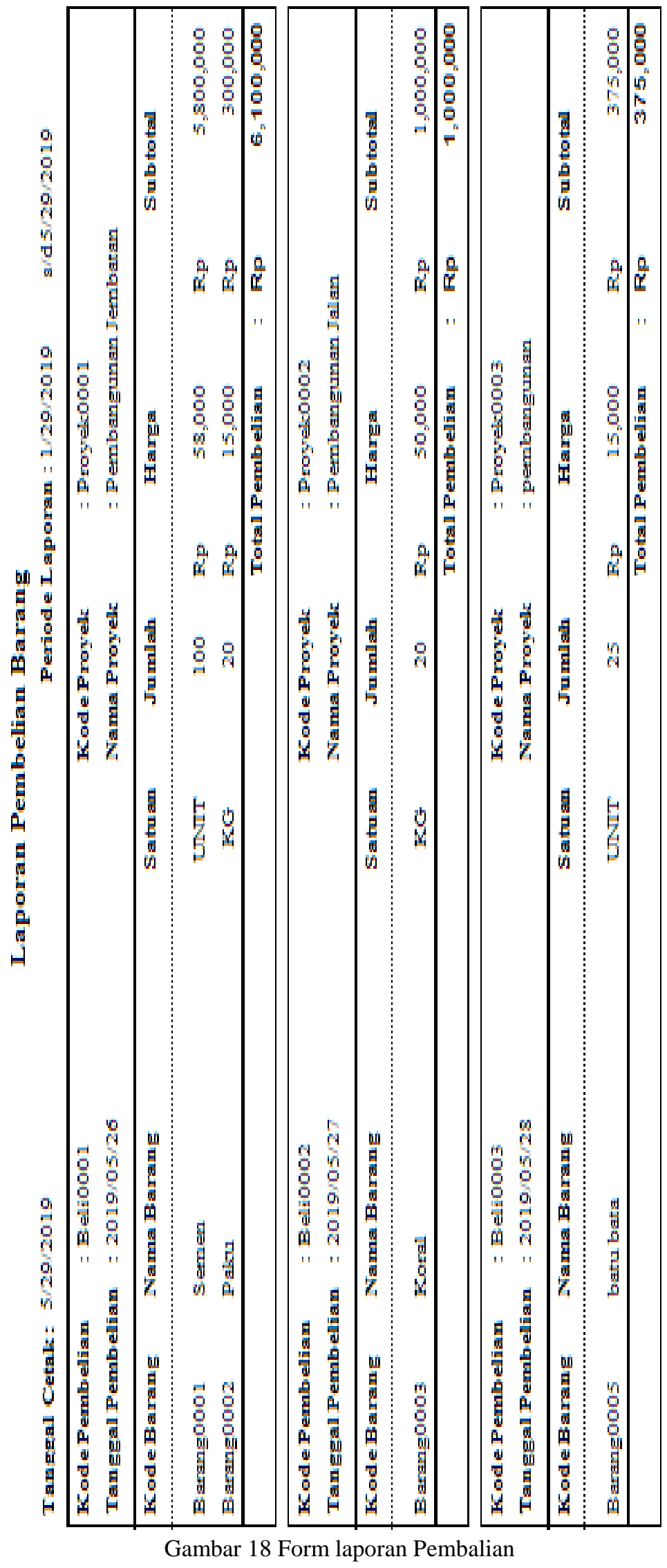




\begin{tabular}{|ccccc}
\hline Tanggal & Kode Proyek & Nama Proyek & Keterangan Biaya & Biaya \\
\hline $2019-05-28$ & Proyek0003 & pembangunan & batu bata & Rp \\
\hline & & Total Bahan Baku Terpakai
\end{tabular}

Gambar 19 Form Laporan Bahan Baku Terpakai

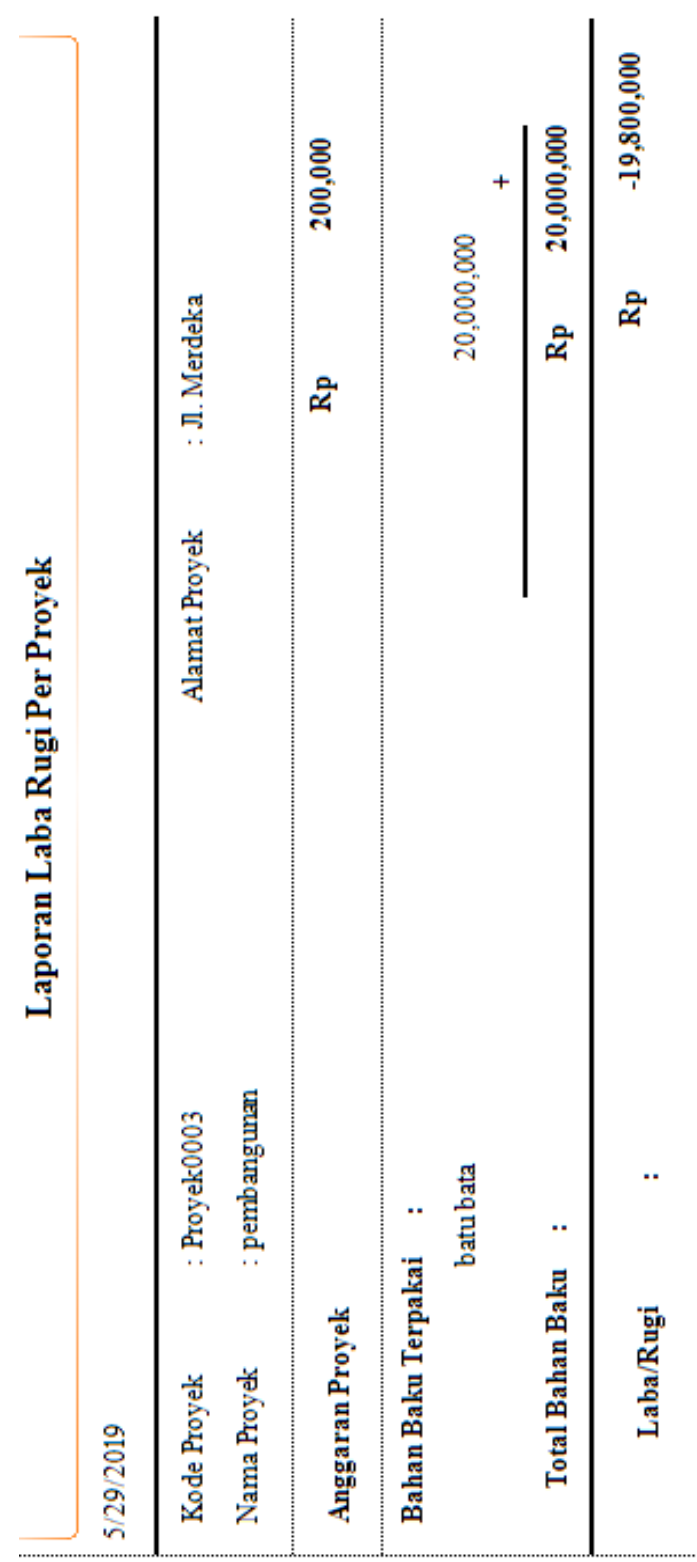

Gambar 20 Form Cetak Data Laba Rugi Proyek 


\section{KESIMPULAN}

Kesimpulan yang dapat diambil dari hasil perancangan perhitungan laba rugi pada PT XYZ adalah:

1. Pembuatan perancangan aplikasi ini diharapkan dapat menyelesaikan permasalan dalam pencatatan laporan laba rugi sehingga menjadi suatu keuntungan pada proses kegiatan pencatatan, dokumentasi, dan efisiensi waktu pengarsipan dan pencarian data.

2. Sebuah sistem informasi yang baik tidak akan terlepas dari perencanaan, analisis dan perancangan. Hal ini dikarenakan dengan adanya perencanaan, analisi, dan perancangan akan mengurangi ketidakefisienan, dan mengurangi bahkan menghilangkan kesalahan yang berulang. Dengan sistem informasi akan meminimalisir kesalahan yang terjadi.

Adapun saran untuk penelitian sejenis, perancangan perhitungan laba rugi pada PT XYZ disarankan untuk diimplementasikan sehingga perancangan aplikasi laba rugi ini dapat digunakan dan bermanfaat bagi perusahaan sejenis maupun pengguna laporan laba rugi lainnya.

\section{DAFTAR PUSTAKA}

[1] E. N. Fitriana, "Analisis Atas Pengakuan Pendapatan Pada Perusahaan Jasa Kontruksi Kaitannya Terhadap Laporan Laba Rugi Perusahaan,” 2015.

[2] E. Iswandy, "SISTEM PENUNJANG KEPUTUSAN UNTUK MENENTUKAN PENERIMAAN DANA SANTUNAN SOSIAL ANAK NAGARI DAN PENYALURANNYA BAGI MAHASISWA DAN PELAJAR KURANG MAMPU DI KENAGARIAN BARUNG - BARUNG BALANTAI TIMUR," J. TEKNOIF, vol. 3, no. 2, 2015.

[3] A. Taqwiym and N. WIjaya, "PERANCANGAN LOWONGAN KERJA ONLINE BERBASIS WEB PADA PT ANH,” J. Ilm. Inform., vol. 2, no. 1, pp. 112-116, 2017.

[4] C. Larman, Applying UML and Patterns: An Introduction to Object-Oriented Analysis and Design and Iterative Development, Third Edition. USA: Addison Wesley Professional, 2004.

[5] D. Buhalis and A. Amaranggana, "Smart Tourism Destinations Enhancing Tourism Experience Through Personalisation of Services," in Information and Communication Technologies in Tourism 2015, 2015, pp. 377-389.

[6] A. R. Djaelani, "Teknik Pengumpulan Data dalam Penelitian Kualitatif," PAWIYATAN, vol. 20, no. 1, 2014.

[7] H. Hasanah, "TEKNIK-TEKNIK OBSERVASI (Sebuah Alternatif Metode Pengumpulan Data Kualitatif Ilmu-ilmu Sosial)," J. At-Taqaddum, vol. 8, no. 1, 2016. 
[8] Indrajani, Perancangan Basis Data dalam All in 1. Jakarta: Elek Media Komputindo, 2011.

[9] F. Nugraha, "ANALISA DAN PERANCANGAN SISTEM INFORMASI PERPUSTAKAAN," SIMETRIS, vol. 5, no. 1, 2014.

[10] N. Wijaya, "PERANCANGAN APLIKASI PROMOSI SONGKET PALEMBANG BERBASIS ANDROID," JUSIM, vol. 2, no. 2, pp. 10-22, 2017.

[11] T. . Hathaway, Data Flow Diagram by Example. USA: BA-Experts, 2015. 